\title{
Theory of Services in MRP and Logistics
}

\author{
Jozef Mihok ${ }^{1 *}$, Jaromír Markovič \\ ${ }^{1}$ Slovak Office of standards, metrology and testing, Bratislava, Slovak republic \\ 2Slovak legal metrology, Banská Bystrica, Slovak republic
}

\section{BIOGRAPHICAL NOTES}

Dr. h. c. prof. Ing. Jozef Mihok, PhD. (born in 1950) received the Ing. and PhD. degrees from Faculty of mechanical engineering of Technical university Košice. In the year 2008 he was appointed as the Professor in the industrial engineering field of study. He is currently President of Slovak Office of standards, metrology and testing in Bratislava. His research interests include industrial engineering and crisis management.

Ing. Jaromír Markovič, PhD. (born in 1960) received the Ing. and PhD. degrees from Faculty of mechanical engineering of Technical university Žilina. He is currently (from 2000) General director of Slovak legal metrology in Banská Bystrica. His research interests include industrial engineering and metrology management.

\section{KEYWORDS}

Theory of services, logistics, indicator, customer.

\section{ABSTRACT}

Knowledge about the orientation of body segments is a vital source of information. It can be Presented article is oriented on theory of services. Theory of services means knowledge of what is permanent and normal in producing a service. Traditionally, this knowledge has been accumulated in tacit form in the professional skill of the people involved in the activity.

\section{Introduction}

Service can be defined as an intangible economic process which satisfies human needs by its own running. It is a result of particular activity/work.

Services offered can be:

- Material - e.g. maintenance and repair services, freight services, trade services, parts of processing industry,

- Non material - e.g. education, science, culture and other unproductive services.

The services, from the point of view of national economy, represent third sector which significantly contributes to gross national product.

In comparison with products, services have special features presented in table 1.

To optimize the services execution and use the tools of marketing mix effectively we need to know the answers for the following questions which characterize the services:

- way of service distribution,

nature of service demand,

- relations between service provider and customer,

- degree of flexibility from the side of service provider. 
Table 1: Selected features of services [1].

\begin{tabular}{|c|c|}
\hline INTANGIBILITY & $\begin{array}{l}\text { - Cannot be touched and examined, the customer buys the service with a certain level of risk } \\
\text { - Main factors of services perception: } \\
\text { - place (exterior, interior), } \\
\text { - personnel offering services (qualified, friendly, flexible), } \\
\text { - suitable services promotion (to address customers). }\end{array}$ \\
\hline INSEPARABILITY & $\begin{array}{l}\text { - service is an entity in its nature, } \\
\text { it is usually provided by a single person - the service executor, the customer is present in the process } \\
\text { of service execution and the interaction is created between the provider and the customer which influ- } \\
\text { ences significantly the final customer decision about buying the service, resp. buying it repeatedly }\end{array}$ \\
\hline VARIABILITY & $\begin{array}{l}\text { - services are extremely variable } \\
\text { it is important who, where and how provides the service which gives the customer a sort of assuran- } \\
\text { ce of purchased services' quality } \\
\text { a for quality increase, the staff has to be chosen and trained properly, customer satisfaction survey has } \\
\text { to be done too inn order to widen and improve the services }\end{array}$ \\
\hline FINITNESS & $\begin{array}{l}\text { - services cannot be stored } \\
\text { services are bound to people and their needs }\end{array}$ \\
\hline
\end{tabular}

Service quality can be defined as an extent to which the services meet the requirements, desires and expectations of the recipient. Every customer has their own understanding of quality. One considers a quality service the one which meets their expectations, the other customer needs a service which overcomes their expectations. This is not related to what service provider considers a quality service. That is why if a company providing services wants to survive, it needs to monitor how customers receive the services as the growth of customer dissatisfaction can lead into a threat to every service provider. Providing quality services is a long term and according to W. E. Deming "never ending process" as it relates to continuous growth of customer demands which have to be respected and only the one who realizes it and finds a way to their own customers will find a way to company success [2].

\section{Logistics Indicators Related to Distribution of Customer Services}

To specify the appropriate level of customer service these service have to be monitored and measured some way. This way, a company receives an overview of the level of services it provides. It is a controlled feedback which helps the company to specify the failures and directly try to improve or completely remove it. This involves: optimization of stock amount, make the processing of orders more effective, fasten the delivery cycle, improve reliability and flexibility of distribution system and the like.
The sequence for customer service measuring can have the following form [3]:

1. definition of customer - who is a real customer of the company,

2. define the customer needs and watch their satisfaction manifestation,

3. suggest a suitable questionnaire for satisfaction measuring highly relevant,

4. specify the number and type of customers to make a sample for quality research,

5. choose suitable and effective method of necessary data collection,

6. create methods and standards for processing and evaluating of collected data, including the methods for satisfaction degree quantification,

7. processed data should be used as inputs of the permanent quality improvement processes.

The relevance of individual parameters can be increased by the use of more parameters. The customer services, then, should be dealt with in complex. From the point of view of distribution, the most important parameters to be watched by the company are:

- extent of provided services - for specification of distribution system performance, e.g. number and structure of orders, number of expeditions, distribution warehouse and channel turnover, storage places size, equipment for transport, manipulation, loading, unloading, packaging

- indicators of degree of offered services complexity - are important for creation of distribution system conception, are part of logistic objectives of 
the company and a sort of lead in relation to sizing of company strategy tasks within its whole logistic chain (purchase, supply, production and distribution), e.g. amount of realized orders, post order service quality, spare parts availability

- delivery cycle length - indicator of flexibility and speed of provided services, it is the time period from the order issuance by the customer till the moment of goods delivery to them.

- Delivery cycle structure can vary (the length of order execution depends on it), either the order is realized from stock (shorter delivery time) or is custom-made (longer delivery time).

- When realizing the order via warehouse the rough structure of the cycle can be as follows:

- Order acceptance,

$\checkmark$ Order processing

$\checkmark$ Commissioning, packaging,

$\checkmark$ Loading, transport,

$\checkmark$ Unloading, acceptance by the customer.
When custom-made, the delivery time is prolonged by the following periods:

- Technical preparation of the production,

- Raw material, semi finished products purchase,

- Own production,

- Technical checking.

When assembling custom-made order the times are as follows:

- Raw material, material, semi finished products, parts and components purchase,

- assembling,

- technical checking

The level and extent of the provided services has strategic meaning as we need to prevent too high costs of product distribution to be reflected in its final price, resp. in the decrease of company revenue. That is why their extent should be regulated depending on the life cycle of the product, Fig.1.

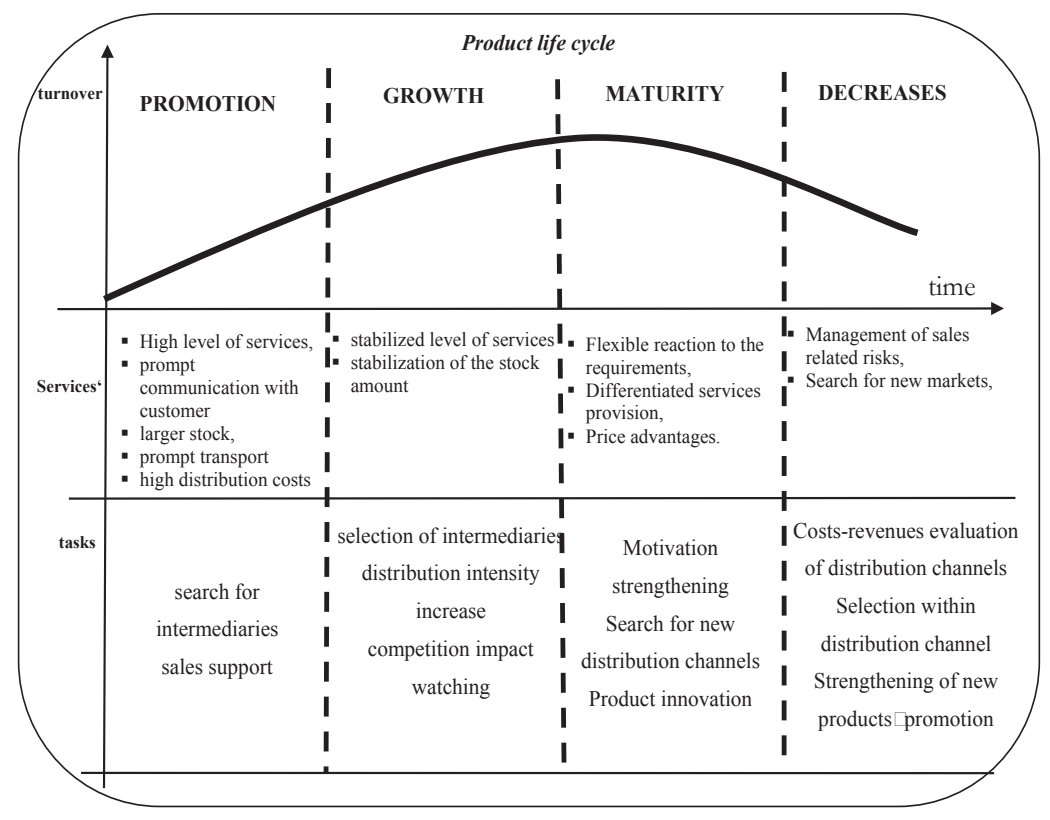

Fig. 1: Level of services offered in the life cycles of the product.

The attempt is to find a compromise between provision of adequate level of services and the level of costs related to them. The effectiveness analysis can be used to optimize the level of services offered in contrast with profits expected or so called searching for turning point (figure 2).

It involves estimation of profits and costs relation per unit (produced, sold). There is a direct depen- dence of profits from sold goods, resp. executed orders. The costs' growth is exponential in relation to services' extent and quality growth. To specify optimum level of customer services it is necessary to estimate to what extent the profits have to be increased along with services improvement so that the costs of services' providing are covered. The error of consumption forecast has to be considered too as it is included in the profit calculation. Optimizing of provided services level is in setting 
of turning point which represents a dividing line between profitable and unprofitable production/ sale.

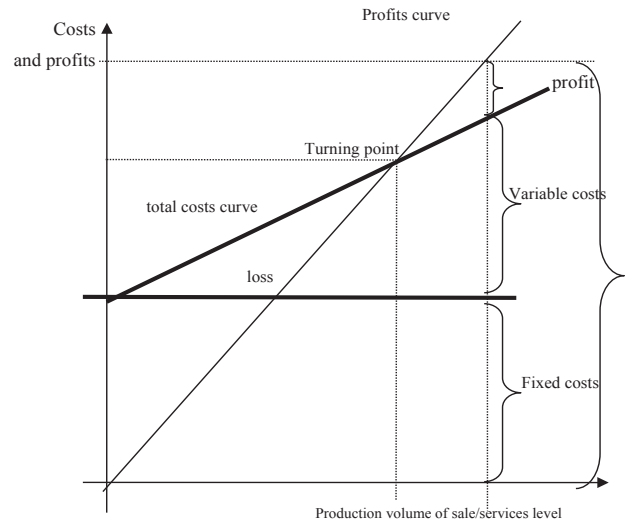

Fig. 2: Turning point analysis.
The possible procedure to specify the level of provided services could be the following [adjusted according to 4].

1. Analysis of the actual state of customer requirements upon the level of provided services

Review of actual and potential future requirements,

- Review of indicators from the point of view of customers' importance such as: product availability, delivery time, information, flexibility, sales problems solving, processing of reclaims and the like,

- monitoring, processing and evaluating of observed variables' development.

2. Customer differentiation from the point of view of importance

- The company sets its own criteria of customer selection to whom it then provides adequate level services (e.g. $A B C$ analysis, multi criteria decision and the like).

Table 2: Selected indicators of distribution logistics [modified by 5, 6].

\section{SELECTED INDICATORS OF DISTRIBUTION LOGISTICS}

STRUCTURAL AND GENERAL INDICATORS $\quad \checkmark$ express the extent and structure of expedition activity, its carriers and structure of costs, volume of sale of individual products, total volume of sale per assortment, number of active and passive customers, number of unloading per time unit, number of stock levels, stock places, average distance between the stock levels, the distance between expedition warehouses and customers,

\begin{tabular}{|c|c|}
\hline INDICATORS OF SALE STRUCTURE & $U_{P}=\frac{\text { volumeofsaleofparticularitem }}{\text { totalvolumeofsale }} * 100[\%]$ \\
\hline AVERAGE SIZE OF ORDER & $\begin{array}{l}\checkmark \text { given by the number of ready products } \\
\overline{O_{v z}}=\frac{\text { numberofreadyproducts }}{\text { numberoforders }}[\text { eur/order }]\end{array}$ \\
\hline AVERAGE TURNOVER PER CUSTOMER & $\overline{O_{z}}=\frac{\text { totalturnover }}{\text { numberofcustomers }}[$ eur $/$ customer $]$ \\
\hline $\begin{array}{l}\text { PRODUCTIVITY INDICATORS } \\
\text { of provided services }\end{array}$ & $\begin{array}{l}\checkmark \text { expresses the ratio of work/output per time unit, it includes: indicator of } \\
\text { expedition productivity(amount of expeditions per working day), orders pro- } \\
\text { cessing (number of orders processed or order units processed per working day, } \\
\text { number of staff at distribution department and the like. } \\
\checkmark \text { The indicators of turnover speed are important as they help to specify how } \\
\text { often the stock turns over in the warehouse per watched time period. The } \\
\text { speed of stock turnover significantly influences storage costs, capital bound } \\
\text { and also has influence on products quality (damage, aging). }\end{array}$ \\
\hline DELIVERY TIME INDICATORS & $U_{D L}=\frac{\sum \text { deliverytimesperobservedtimeperiod }}{\text { numberofdeliveriesperobservedtimeperiod }}[$ days/deliveries $]$ \\
\hline EXPEDITION PRODUCTIVITY & $P_{E x C}=\frac{\text { numberofdeliveriesperobservedtimeperiod }}{\text { thelengthofobservedperiod }}[$ delivery $/$ day $]$ \\
\hline TRANSPORT SPEED & $R_{\text {dopr. }}=\frac{\text { timeconsumptionperobservedperiod }}{\text { numberofdeliveriesperobservedtimeperiod }}[$ days/deliveries $]$ \\
\hline INDICATOR OF TURNOVER SPEED & $O_{R}=\frac{\text { turnoverperobservedtimeperiod }}{\text { averagestock }}[$ howmanytimes $]$ \\
\hline
\end{tabular}




\begin{tabular}{|l|l|}
\hline AVERAGE SPEED OF WARRANTY REPAIRS & $\bar{R}_{\text {zopr }}=\frac{\sum \text { timeofrepairs }}{\text { numberofrepairsperobservedperiod }}[$ time $/$ repair $]$ \\
\hline AVERAGE SPEED OF RECLAIMS PROCESSING & $R_{V \text { Reklaml }}=\frac{\sum \text { timeofreclaimproces } \sin g}{\text { numberofreclaimsperobservedtimeepriod }}[$ time $/$ reclaim $]$ \\
\hline
\end{tabular}

Table 2: Selected indicators of distribution logistics [modified by 5,6].

\section{SELECTED INDICATORS OF DISTRIBUTION LOGISTICS}

\section{ECONOMY INDICATORS}

of provided services

COSTS OF CUSTOMER ORDERS'
PROCESSING

$\checkmark$ Express how the company could reduce the costs of distribution, e.g. costs of customer orders' processing, their proportion in total turnover, distribution costs per order, proportion of distribution costs, distribution costs per one transport contract,

\section{The following are considered}

$\checkmark$ Wage costs, software costs, services costs, capital costs, stock keeping costs, storage costs etc. including wrong amount costs.

$\checkmark$ Repeated sale costs,

$\checkmark$ Additional orders and express goods costs,

$\checkmark$ Delayed delivery costs reducing the net profit,

$\checkmark$ Costs of unpaid allowances.

$\bar{N}_{\text {vobj }}=\frac{\text { total cos tsoforderproces } \sin g}{\text { numberofprocessedorders }}[$ eur/order $]$

OWN TO FOREIGN TRANSPORT COSTS` RATE $N_{D}=\frac{\text { owntransport } \cos t s}{\text { foreigntransport } \cos t s} * 100[\%]$

\section{QUALITY INDICATORS}

of provided services

DELIVERYREADINESS

\begin{tabular}{|c|c|}
\hline DELIVERY READINESS & $D_{P}=\frac{\text { numberofpromptlyprocessedorders }}{\text { totalnumberoforders }} * 100[\%]$ \\
\hline
\end{tabular}

\begin{tabular}{|l|l|}
\hline DELIVERY ACCURACY & $D_{P R}=\frac{\text { numberofitemsdelievredintime }}{\text { totalnumberofdelievereditems }} * 100[\%]$ \\
\hline WRONG DELIVERY RATE & $P_{C h}=\frac{\text { numberofdeliverieswithvariationintime }}{\text { totalnumberofdeliveries }} * 100[\%]$ \\
\hline RECLAIMS RATE & $P_{\text {Rekl }}=\frac{\text { numberofreclaimeddeliveries }}{\text { totalnumberofdeliveries }} * 100[\%]$ \\
\hline $\begin{array}{l}\text { AVERAGE TIME OF ADDITIONAL OREDER } \\
\text { DELIVERY }\end{array}$ & $\bar{C}_{\text {DodDod }}=\frac{\sum \text { oftimeneededforadditionaldelivery }}{\text { numberofadditionaldelivery }}[$ days $]$ \\
\hline SPARE PARTS AVAILABILITY & $P_{C h}=\frac{\text { numberofsparepartsfromstock }}{\text { totalnumberofspareparts }} 100[\%]$ \\
\hline
\end{tabular}

Designation of provided services level

- Based on compromise between the services level and related costs,

- Realized in following steps:

$\checkmark$ Compare the own services offered with the services of competition,

- Consider own capacity, financial and personnel options for provision of chosen level of services,

- Consider outsourcing of particular services storage, packaging, transport, distribution chan- nels, after sales service

$\checkmark$ Quantify potential benefits from the provided services,

$\checkmark$ Determine target level of services for the future and conditions for its achieving,

$\checkmark$ Take strategic decisions in the fields of purchase, production and distribution.

Selected indicators of distribution logistics can be divided into groups as presented in table 2 . 


\section{Conclusion}

In conclusion, this paper has provided the building blocks for the theory of services that can explain the role and characteristics of services in industry. The understanding of this theory must be related with knowledge transfer between customer and producer.

Customer is the key partner for the company. P. F. Ducker (one of the 20th century greatest thinkers in the field of management and enterprising) considers a satisfied customer to be the main point of every business activity. Besides politics, in business there also exists the term of business democracy, the companies are controlled by customer wishes and requirements and every activity of the company is aimed at their maximum satisfaction.

Knowing the customer ensures quality communication within the company both in vertical and horizontal ways. The employees of the company are a great contribution to the process since they are in every day personal contact with the customers, resolving their requirements or reclaims.

\section{Acknowledge}

This article was created by implementation of the grant project KEGA 004TUKE-4/2013 Intensification of modelling in teaching II. and III. degree in the field of study 5.2.52 Industrial Engineering.

\section{References}

[1] Fl'0, M., et al.: PLM systems and Tecnomatix Plant Simulation, a description of the environment, control elements, creation simulations and models. In: American Journal of Mechanical Engineering. Vol. 1, no. 7 (2013), p. 165-168. - ISSN 2328-4102

[2] PEKARČÍKOVÁ, M. - TREBUŇA, P.: Modeling of business logistics chains / Miriam Pekarč́ková, Peter Trebuňa - 2011. - 1 elektronický optický disk (CD-ROM). In: MMaMS 2011 : Modelling of Mechanical and Mechatronical Systems : proceedings of the 4th international conference: Herlany, Slovakia, 20. - 22.9. 2011. - Košice: SjF TU, 2011 S. 400-403. - ISBN 978-80-553-0731-2

[3] http://kix.ffv.cvut.cz/ demel/ped/ov/ov.pdf

[4] SCHULtE, Ch.: Logistika, VICTORIA PUBLISHING, Praha, 1994

[5] MAGULÁKOVÁ, M: Vplyv logistických činností na zvyšovanie konkurencieschopnosti podniku, in: zb. príspevkov z 8. celoštátnej konferencie doktorandov strojníckych fakúlt technických univerzít a vysokých škôl, zborník recenzovaných príspevkov (cd), košice /9.11. 2005/, isbn: 80-8073-354-6, str. 243 - 246.

[6] MELOUN, M. - MILITKÝ, J.: Statistická analýza experimentálních dat. Praha: Academia. 2004. 953 s. ISBN 80-200-1254-0

[7] TREBUŇA, P., FI'OO, M., PEKARČÍKOVÁ, M..Komparácia spracovania plastov dvojfarebnou potlačou a IML technológiu pomocou Petriho sietí, In: Logistický monitor. Č. jún (2012), s. 1-10. - ISSN 1336-5851 Spôsob prístupu: http://www.logistickymonitor. sk/images/prispevky/trebuna-6-2012.pdf. 